\title{
IRRIGATION INTERVALS IN THE PRODUCTION OF ORNAMENTAL PINEAPPLE IN POTS ${ }^{1}$
}

\author{
GUILHERME VIEIRA DO BOMFIM ${ }^{2}$, MÁRCIO DAVI SILVA SANTOS ${ }^{2}$, BENITO MOREIRA DE AZEVEDO ${ }^{2}$, ANA \\ CRISTINA PORTUGAL PINTO DE CARVALHO ${ }^{3 *}$, CARLOS NEWDMAR VIEIRA FERNANDES $^{4}$
}

\begin{abstract}
Information on irrigation management is essential in a production system for the commercial cultivation of ornamental pineapple in pots. As such, this work evaluated the effects of irrigation interval on the growth and production of the crop in pots. The experiment was carried out from 16/07/2015 to 21/05/2016 in a greenhouse located in Fortaleza, in the state of Ceará, Brazil. The experimental design was completely randomised, with five treatments, four replications and four plants per plot. The treatments consisted of irrigation intervals of 2, 4, 6, 8 and 10 days. The plants were grown in one-litre pots, fertilised with slow release fertiliser and subjected to supplementary drip irrigation. The following variables were analysed at the end of the cycle (402 days): number of leaves; length and width of the 'D' leaf; diameter of the rosette; plant height; rate of flowering; length and diameter of the peduncle, syncarp and crown; crown to syncarp ratio; and percentage of commercial plants. The irrigation interval influenced the number of leaves, length of the 'D' leaf, diameter of the rosette, plant height, rate of flowering and percentage of commercial plants. Irrigating every two days resulted in water savings, increased leaf growth and a high rate of flowering, and the greatest percentage of commercial plants. Irrigating at intervals of between four and 10 days, increased water wastage, and reduced leaf growth, the rate of flowering and the percentage of commercial plants. The shortest irrigation interval is therefore the most recommended for cultivation in pots.
\end{abstract}

Keywords: Ananas comosus var. erectifolius. Ornamental plants. Irrigation management.

\section{INTERVALOS DE IRRIGAÇÃO PARA PRODUÇÃO DE ABACAXIZEIRO ORNAMENTAL EM VASO}

RESUMO - Informações sobre manejo da irrigação são imprescindíveis no sistema de produção destinado ao cultivo comercial de abacaxizeiro ornamental em vaso. Por isso, este trabalho avaliou os efeitos de intervalos de irrigação sobre o crescimento e produção da cultura em vaso. O experimento foi realizado entre 16/7/2015 e 21/5/2016, em telado antiafídeo, em Fortaleza, Ceará, Brasil. O delineamento experimental foi o inteiramente casualizado, com cinco tratamentos, quatro repetições e quatro plantas por parcela. Os tratamentos consistiram nos intervalos de irrigação de: 2; 4; 6; 8; e 10 dias. As plantas foram cultivadas em vasos de um litro, adubadas com fertilizante de liberação lenta e submetidas a irrigação suplementar por gotejamento. Foram analisadas no final do ciclo (402 dias) as variáveis: número de folhas; comprimento e largura da folha ' $\mathrm{D}$ '; diâmetro da roseta; altura da planta; taxa de floração; comprimento e diâmetro do pedúnculo, sincarpo e coroa; relação coroa/sincarpo; e percentagem de plantas comerciais. Os intervalos de irrigação influenciaram o número de folhas, comprimento da folha ' $\mathrm{D}$ ', diâmetro da roseta, altura da planta, taxa de floração e percentagem de plantas comercias. A irrigação realizada a cada dois dias resultou em economia de água, crescimento foliar e taxa de floração elevados e na maior percentagem de plantas comerciais. Irrigações com intervalos entre quatro e 10 dias aumentaram o desperdício de água e reduziram o crescimento foliar, taxa de floração e percentagem de plantas comerciais. O menor intervalo de irrigação é, portanto, o mais recomendado para a modalidade de cultivo em vaso.

Palavras-chave: Ananas comosus var. erectifolius. Plantas ornamentais. Manejo de irrigação.

\footnotetext{
${ }^{*}$ Corresponding author

${ }^{1}$ Received for publication in $09 / 12 / 2019$; accepted in $11 / 28 / 2019$.

Paper extracted from the doctoral thesis of the second author

${ }^{2}$ Department of Agricultural Engineering, Universidade Federal do Ceará, Fortaleza, CE, Brazil, guile2007@gmail.com - ORCID: 00000002-4603-4092, marciodavy@yahoo.com.br - ORCID: 0000-0002-2890-8980, benitoazevedo@hotmail.com - ORCID: 0000-0001-73911719.

${ }^{3}$ Plant Tissue Culture Laboratory, Embrapa Agroindústria Tropical, Fortaleza, CE, Brazil, acflororquidea@gmail.com - ORCID: 00000002-4562-8999.

${ }^{4}$ Department of Education, Instituto Federal de Educação Ciência e Tecnologia do Ceará, Iguatu, CE, Brazil, newdmar@gmail.com ORCID: 0000-0001-8678-021X.
} 


\section{INTRODUCTION}

The ornamental pineapple is a tropical plant of importance in the agribusiness of flowers and ornamental plants (LIMA et al., 2017). Due to its exotic appearance, abundance of colours and longevity, the crop has varieties (e.g. Ananas comosus var. bracteatus, ananassoides and erectifolius) that can be marketed in the cut-flower, foliage, landscaping and gardening, and potted-plant sectors (ALVES et al., 2014; SOUZA et al., 2014).

The most important variety economically is Ananas comosus var. erectifolius (L. B. Smith) Coppens et Leal, an exotic tropical plant, whose striking morphological feature is its purple colour and the absence of spines (SOUZA et al., 2007). In the Northeast of Brazil, marketing of the crop is aimed at both the cut-flower sector, where it is better known, and to the promising potted-plant sector (SOUZA et al., 2012a; PEREIRA et al., 2018).

As it is a new activity, the commercial production of potted ornamental pineapple lacks information on the use and management of production factors. Existing information, besides not being exclusive to the variety erectifolius, is scarce and restricted to a few topics, such as genetic improvement, fertilisation, nutrition and physiology (REIS et al., 2007; MENDES et al., 2011; HAWERROTH et al., 2014; SOUZA et al., 2014; VIÉGAS et al., 2014; BARBOSA et al., 2015; LIMA et al., 2017).

Information on irrigation, for example, is virtually non-existent. Despite the relevance of irrigation to the sustainability of the agribusiness of flowers and ornamental plants (JUNQUEIRA; PEETZ, 2018), existing research largely applies to the edible variety (Ananas comosus var. comosus (L.) Merril) (CARR, 2012).

Irrigation of the potted ornamental pineapple relies on the experience of the producer, and is carried out by spraying and with the use of excessive irrigation depths and frequencies (two daily one-hour pulses). As reported by the producers, such management, increases the loss of water (percolation and drift) and nutrients (leaching), and the appearance of pests, such as the mealybug (Dysmicoccus brevipes), and of diseases, such as eye rot (Phytophthora nicotianae var. parasitica).

The above problems can be minimised by adopting strategies aimed at economising on water resources. Some of these strategies, including those already studied for the edible pineapple, refer to the use of drip irrigation (CARR, 2012) and an increase in the irrigation interval (FRANCO et al., 2014).

The irrigation intervals used for growing edible pineapple in the open are flexible, and typically range from two to seven days (AZEVEDO et al., 2007; SOUZA et al., 2012b; SANTANA et al.,
2013). This flexibility is mainly due to the acid metabolism of crassulaceae (CAM), which affords the crop a high level of water use efficiency and resistance to water deficit (BRITO et al., 2017; CARR, 2012). As they belong to the same species, the ornamental variety could supposedly be irrigated at greater intervals, similar to those of the edible variety. The increase in irrigation interval, however, should be adjusted through experimentation, as the two varieties are grown differently.

Considering the lack of information on irrigation in the potted ornamental pineapple, the aim of this study was to evaluate the effects of five irrigation intervals, based on irrigation frequencies used with the edible variety, on the growth and production of Ananas comosus var. erectifolius grown in a protected environment.

\section{MATERIAL AND METHODS}

The experiment was carried out between $16 / 7 / 2015$ and $21 / 5 / 2016$ in a greenhouse covered with anti-aphid screen (50 mesh) at the Federal University of Ceará, in Fortaleza, Ceará, Brazil (344'45" S, 38 34'55" W, at an altitude of $19.5 \mathrm{~m}$ ).

According to the Köppen classification, the climate in the region is of type Aw', characterised as rainy tropical, tropical savannah, with the driest period during the winter and maximum rainfall during the summer-autumn. During the experimental period, data on air temperature, relative humidity, wind speed, rainfall and reference evapotranspiration were obtained daily by means of a digital weather station installed inside the greenhouse (Figure 1).

According to Figure 1, there were no atypical variations in climate in the region during the experiment. The maximum, minimum and mean values for the maximum air temperature, minimum air temperature, relative humidity and wind speed were $32.6,25.6$ and $30.9^{\circ} \mathrm{C} ; 25.2,19.8$ and $22.9^{\circ} \mathrm{C}$; 98.3, 54.3 and $74.2 \%$; and $6.7,3.7$ and $5.4 \mathrm{~m} \mathrm{~s}^{-1}$ respectively. Rainfall totalled $1,099.6 \mathrm{~mm}$, and occurred mainly between January and May 2016. The total reference evapotranspiration was $1,698.8 \mathrm{~mm}$, with respective maximum, minimum and mean values of $6.7,3.5$ and $5.4 \mathrm{~mm}$.

The seedlings used in the experiment were of the variety Ananas comosus var. erectifolius, produced by micropropagation, and acclimatised for two months (15/4/2015 to $15 / 6 / 2015)$ in $70 \%$ shade.

The acclimatised seedlings were selected and transplanted to pots on 16/6/2015. Black, coneshaped plastic pots with an approximate volume of $1.0 \mathrm{~L}(13.9 \mathrm{~cm}$ wide, $11.6 \mathrm{~cm}$ high and $10.2 \mathrm{~cm}$ deep) were used, and distributed over the cement surface of the greenhouse at a spacing of $15 \mathrm{~cm} \mathrm{x}$ $15 \mathrm{~cm}$. 


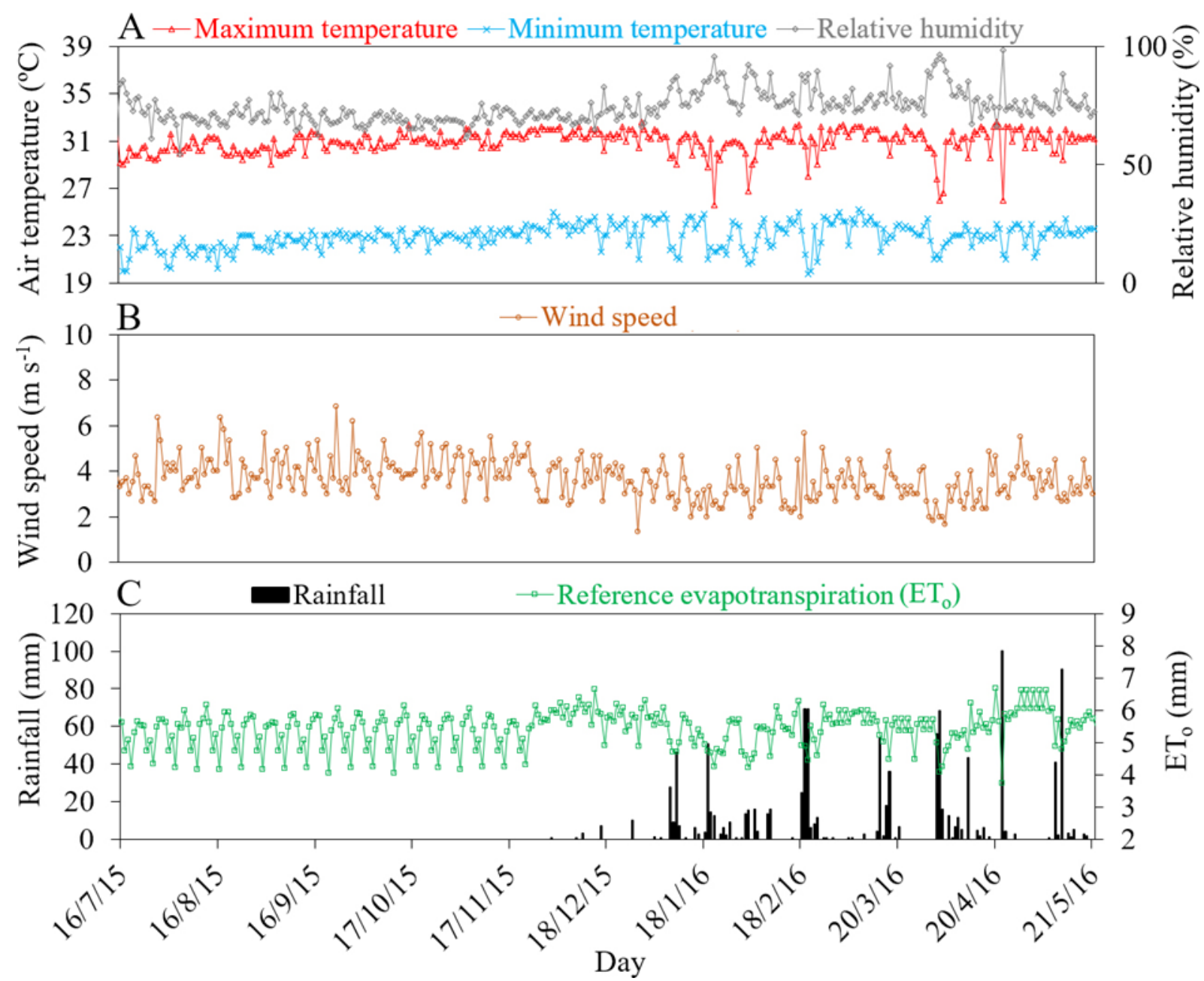

Figure 1. Daily data for air temperature and relative humidity (A), wind speed (B), rainfall and reference evapotranspiration (C) during the experiment with potted ornamental pineapple (Ananas comosus var. erectifolius), carried out in a greenhouse, in Fortaleza, Ceará, Brazil.

The pots were filled with HS Florestal $^{\circledR}$ organic substrate, comprising composted pine bark, vegetable peat and vermiculite. The main physicochemical characteristics were a WRC (water retention capacity at a pressure of $10 \mathrm{~cm} \mathrm{H}_{2} \mathrm{O}$ ) of $51.4 \%$, dry density of $290.2 \mathrm{~kg} \mathrm{~m}^{-3}$, organic $\mathrm{C}$ of $147.5 \mathrm{~g} \mathrm{~kg}^{-1}$, total $\mathrm{N}$ of $4.2 \mathrm{~g} \mathrm{~kg}^{-1}, \mathrm{C} / \mathrm{N}$ ratio of 35.2 , $\mathrm{P}$ (Mehlich extractor) $93.7 \mathrm{mg} \mathrm{L}^{-1}$, K (Mehlich extractor) $435 \mathrm{mg} \mathrm{L}^{-1}$, Ca $53.1 \mathrm{mg} \mathrm{L}^{-1}, \mathrm{Mg}_{2} 38 \mathrm{mg} \mathrm{L}^{-}$ 1, a CEC of $475.3 \mathrm{mmol}_{\mathrm{c}} \mathrm{kg}^{-1}, \mathrm{pH}$ (in water) of 5.0 and $\mathrm{EC}$ of $0.9 \mathrm{dS} \mathrm{m}^{-1}$.

Mineral fertilisation was carried out using Osmocote $^{\circledR}$ Plus 15-09-12 slow-release fertiliser, with a duration of approximately three months. The fertiliser contained: $15 \% \mathrm{~N}, 9 \% \mathrm{P}, 12 \% \mathrm{~K}, 1.30 \%$ $\mathrm{Mg}, 5.90 \% \mathrm{~S}, 0.02 \%$ Bo, $0.05 \% \mathrm{Cu}, 0.46 \% \mathrm{Fe}$, $0.06 \% \mathrm{Mn}, \quad 0.02 \% \quad \mathrm{Mo}$ and $0.05 \% \mathrm{Zn}$. The recommended dose of $13.9 \mathrm{~g}$ per pot (HAWERROTH et al., 2014) was split into three applications, one every three months, starting from when the plants were transplanted.

The surface drip irrigation system consisted of a water reservoir, pump unit, main lines of polyvinyl chloride $(\phi=20 \mathrm{~mm})$, submain and lateral lines of low density polyethylene $(\phi=16 \mathrm{~mm})$, stopcocks, glycerine-filled pressure gauge, disc filter and compensating drippers that were arranged close to the plant roots using microtubes. The estimated coefficient of distribution uniformity (CDU) and mean flow rate of the emitters were estimated at $95 \%$ and $3.2 \mathrm{~L} \mathrm{~h}^{-1}$.

The water used for irrigation, classified as $\mathrm{C}_{2} \mathrm{~S}_{1}$ (moderate risk of salinity and low risk of sodicity), had the following chemical characteristics: $\mathrm{Ca}-1.0 \mathrm{mmol}_{\mathrm{c}} \mathrm{L}^{-1}, \mathrm{Mg}-1.7 \mathrm{mmol}_{\mathrm{c}} \mathrm{L}^{-1}, \mathrm{Na}-4.3$ mmolc L $^{-1}, \mathrm{~K}-0.2 \mathrm{mmol}_{\mathrm{c}} \mathrm{L}^{-1}, \mathrm{Cl}-3.8 \mathrm{mmol}_{\mathrm{c}} \mathrm{L}^{-1}$, $\mathrm{HCO}_{3}-3.6 \mathrm{mmol}_{\mathrm{c}} \mathrm{L}^{-1}, \mathrm{EC}-0.73 \mathrm{dS} \mathrm{m}{ }^{-1}$, SAR - 3.81 and $\mathrm{pH}-7.9$.

To promote their adaptation to the growing environment, the seedlings were subjected to daily irrigation with $0.15 \mathrm{~L}$ of water for one month. On $16 / 7 / 2015$, the different treatments were introduced following the experimental design.

The experimental design was completely randomised, with five treatments, four replications and four plants per plot. The treatments consisted of irrigation intervals of 2, 4, 6, 8 and 10 days.

Supplementary irrigation was carried out to 
replace crop evapotranspiration estimated for the edible pineapple (Equation 1).

$$
\mathrm{ET}_{\mathrm{c}}=\mathrm{ET}_{\mathrm{o}} \times \mathrm{K}_{\mathrm{c}}
$$

where:

$\mathrm{ET}_{\mathrm{c}}=$ crop evapotranspiration $\left(\mathrm{mm} \mathrm{day}^{-1}\right)$

$\mathrm{ET}_{\mathrm{o}}=$ reference evapotranspiration $\left(\mathrm{mm} \mathrm{day}^{-1}\right)$;

$\mathrm{K}_{\mathrm{c}}=$ crop coefficient (dimensionless).

The $\mathrm{ET}_{\mathrm{o}}$ was calculated with the PenmanMonteith methodology (ALLEN et al., 2006), using the mean daily data from the weather station installed inside the greenhouse. The $\mathrm{K}_{\mathrm{c}}$ of the edible pineapple varied according to the phenological phases of the crop: 0.6 during phase I (1-60 days), from 0.6 to 1.2 during phase II (61-210 days), 1.2 during phase III (211-270 days) and from 1.2 to 0.6 during phase IV (271-360 days) (ALMEIDA, 1995). For the different treatments, the $\mathrm{K}_{\mathrm{c}}$ was interpolated from 0.7 to 1.2 during phase II (120 days), 1.2 during phase III (90 days) and from 1.2 to 0.6 during phase IV (102 days).

Supplementary irrigation was calculated as per Equation 2.

$$
\mathrm{Id}=\mathrm{ET}_{\mathrm{c}}-\mathrm{P}_{\mathrm{e}}
$$

where:

Id = irrigation depth $\left(\mathrm{mm} \mathrm{dia}^{-1}\right)$;

$\mathrm{ET}_{\mathrm{c}}=$ crop evapotranspiration for the edible pineapple $\left(\mathrm{mm} \mathrm{day}^{-1}\right)$;

$\mathrm{P}_{\mathrm{e}}=$ effective precipitation or rainfall $\left(\mathrm{mm} \mathrm{day}^{-1}\right)$.
The Id accumulated as per the irrigation frequencies of $2,4,6,8$, and 10 days. $\mathrm{P}_{\mathrm{e}}$ was considered to be any rainfall of less than $9.8 \mathrm{~mm}$; this was taken as the largest water depth that could be captured by the pot (area of $0.0152 \mathrm{~m}^{2}$ ) and retained by the substrate (mean weight of $0.29 \mathrm{~kg}$ and $\mathrm{WRC}$ of $51.4 \%$ ). The Id was applied considering the distribution uniformity of water as equal to $95 \%$.

The $\mathrm{ET}_{\mathrm{c}}, \mathrm{P}_{\mathrm{e}}$ and Id were quantified during phenological stages II, III and IV, with the aim of evaluating the pattern of water demand and availability for the crop throughout the experimental stage.

The volume of water applied at the irrigation intervals of 2, 4, 6, 8 and 10 days, as well as from the rainfall, were compared graphically with the volume of water retained by the substrate at field capacity, to evaluate possible water loss through percolation and nutrient loss through leaching. The water content at field capacity, for a mean weight and WRC of 0.29 $\mathrm{kg}$ and $51.4 \%$, was estimated at $0.15 \mathrm{~L}$.

Crop treatments were carried out weekly, and consisted of cleaning the screen, the manual removal of dry leaves and tillers, and floral induction.

Floral induction took place nine months after transplanting (16/3/2016), using an ethephon-based solution. The solution was prepared with $1 \mathrm{~L}$ of water, $0.45 \mathrm{~mL}$ Ethrel $^{\odot}$ (0.324 $\mathrm{g}$ ethephon), $0.35 \mathrm{~g}$ calcium hydroxide and $20 \mathrm{~g}$ urea. Each plant received $30 \mathrm{~mL}$ of the solution, applied manually to the region of the apical bud using a plastic cup. After 35 days of floral induction $(20 / 4 / 2016)$, the flower buds were formed, with the fruit forming in most plants 30 days later $(20 / 5 / 2016)$.

The principal stages of the experiment can be seen in Figure 2.

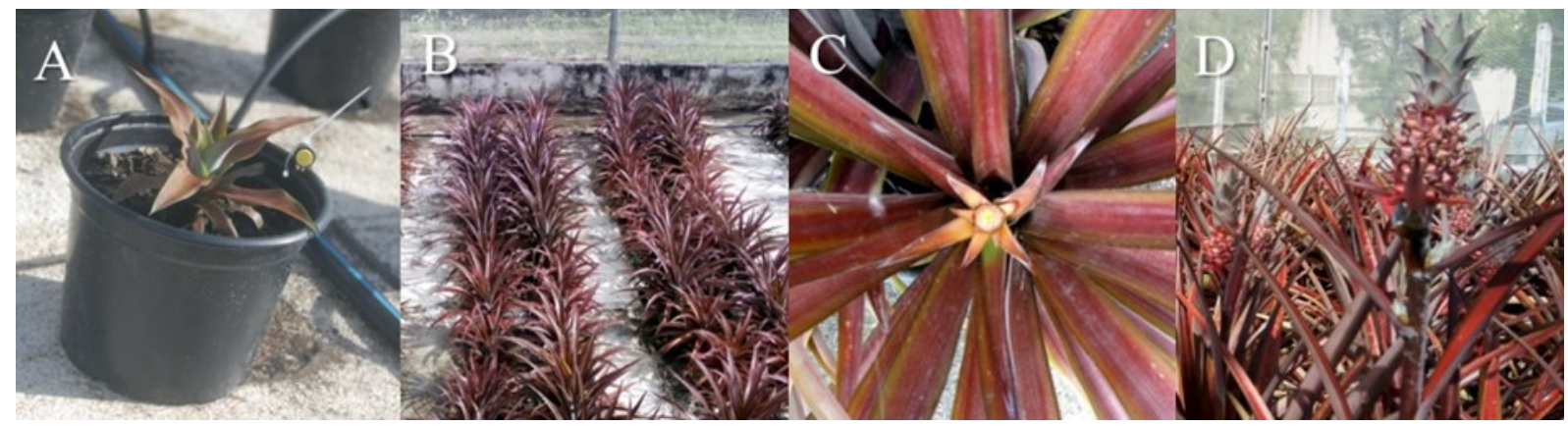

Figure 2. Adaptation (a), leaf growth (b), floral initiation (c) and formation of the infructescence (d) in the ornamental pineapple (Ananas comosus var. erectifolius) grown in pots, during the experiment carried out in a greenhouse $(16 / 7 / 2015$ to 21/5/2016), in Fortaleza, Ceará, Brazil.

After formation of the fruit (21/5/2015), characterised by the closing of the last flower, the following variables were evaluated: number of leaves; length and width of the longest leaf ('D' leaf); diameter of the rosette; plant height; rate of flowering; length and diameter of the peduncle, syncarp and crown; crown to syncarp ratio; and percentage of commercial plants.

All the plants in a plot were used to measure the number of leaves, length and width of the ' $\mathrm{D}$ ' leaf, diameter of the rosette and plant height, as well as to estimate the rate of flowering and percentage of commercial plants. To measure the other variables, two floral stems were used per plot.

The number of leaves was obtained by counting the leaves on each plant. The length of the 'D' leaf was measured from the stem insertion to the leaf apex. The width of the 'D' leaf was measured 
from one edge of the leaf to the other at the widest point. The diameter of the rosette was measured between the apices of two leaves in opposite directions. Plant height was measured from the root collar to the apex of the highest leaf. All the measurements were taken with the aid of a tape measure.

The rate of flowering was estimated by dividing the number of plants with an infructescence by the total number of plants. The length of the peduncle was measured from its insertion in the leaves to the base of the syncarp. The diameter of the peduncle was measured at half its height. The length of the syncarp and crown were measured as the distance between their poles. The diameter of the syncarp and crown were measured around their central region. The crown to syncarp ratio was estimated by dividing their lengths. All the measurements were taken with the aid of a digital calliper.

The percentage of commercial plants was estimated as the ratio between the number of commercial plants and the total number of plants.
Commercial plants were considered those that presented no aesthetic problems in the leaves or floral stems (deformity, wilting, discolouration, chlorosis, necrosis or spots) and those classified for use in pots: height $<65.0 \mathrm{~cm}$, diameter of the rosette $<80.0 \mathrm{~cm}$, length of the 'D' leaf $<60.0 \mathrm{~cm}$, length and diameter of the syncarp $<5.0 \mathrm{~cm}$, and crown to syncarp ratio of up to 1.5 (SOUZA et al., 2007; 2012a).

The mean data of the response variables were subjected to analysis of variance (ANAVA) by Ftest, and the mean values compared by the ScottKnott test $(\mathrm{P}<0.05)$.

\section{RESULTS AND DISCUSSION}

\section{Water demand and availability during the experimental stage}

Water demand and availability for each phenological phase of the ornamental pineapple are shown in Table 1.

Table 1. Water demand and availability during the phenological phases of the ornamental pineapple (Ananas comosus var. erectifolius) grown in pots, in the experiment carried out in a greenhouse (16/7/2015 to 21/5/2016), in Fortaleza, Ceará, Brazil.

\begin{tabular}{|c|c|c|c|c|c|c|c|c|c|c|c|}
\hline \multicolumn{3}{|c|}{ Phase II (120 days) } & \multicolumn{3}{|c|}{ Phase III (90 days) } & \multicolumn{3}{|c|}{ Phase IV (102 days) } & \multicolumn{3}{|c|}{ Phase II - IV (312 days) } \\
\hline $\mathrm{ET}_{\mathrm{c}}$ & $\mathrm{P}_{\mathrm{e}}$ & Id & $\mathrm{ET}_{\mathrm{c}}$ & $\mathrm{P}_{\mathrm{e}}$ & Id & $\mathrm{ET}_{\mathrm{c}}$ & $\mathrm{P}_{\mathrm{e}}$ & Id & $\mathrm{ET}_{\mathrm{c}}$ & $\mathrm{P}_{\mathrm{e}}$ & Id \\
\hline 599.6 & 0.0 & 599.6 & 601.5 & 173.1 & 466.7 & 516.6 & 235.7 & 350.7 & 1717.8 & 408.8 & 1430.7 \\
\hline
\end{tabular}

$\mathrm{ET}_{\mathrm{c}}=$ crop evapotranspiration for the edible pineapple; $\mathrm{P}_{\mathrm{e}}=$ effective precipitation; $\mathrm{Id}=$ irrigation depth.

Crop evapotranspiration $\left(\mathrm{ET}_{\mathrm{c}}\right)$ showed an increase of $0.33 \%$ between phases II and III, and a decrease of $14.1 \%$ between phases III and IV. The reduction in $\mathrm{ET}_{\mathrm{c}}$ during this period was due to an increase of $36.2 \%$ in the amount of rainfall. Full irrigation (no rainfall) was applied during phenological phase II, and supplementary irrigation (with rainfall) during phenological phases III and IV. In terms of water volume, each plant received the amount of $0.0,2.7$, and $3.6 \mathrm{~L}$ from the effective rainfall, and 9.2, 7.2 and 5.6 L from irrigation during phenological phases II, III and IV respectively. During the cycle, each plant received $28.3 \mathrm{~L}$ of water, $6.3 \mathrm{~L}$ from the effective rainfall and $22 \mathrm{~L}$ from irrigation.

The volume of rainfall and irrigation during the experiment, considering the individual values for each irrigation interval, are shown in Figure 3.

For the irrigation interval of two days (Figure $3 \mathrm{~A}$ ), the volume of accumulated water during each phenological phase was close to the maximum limit for water retention by the substrate (estimated at 0.15 L). This can be explained by the reduced water consumption of the species, which is a function of the acid metabolism of crassulaceae (DAVIS et al.,
2019), and the shorter period required for the daily accumulation of the irrigation depths.

At the intervals of $4,6,8$ and 10 days (Figures $3 \mathrm{~B}$ to $3 \mathrm{E}$ ), although the daily water volume estimated for the crop was small, after four days, the total volume eventually exceeded the water retention capacity of the substrate. In this case, the increase in the irrigation interval, despite possibly improving water distribution in the substrate by increasing the irrigation time, must have intensified water and nutrient loss due to excessive drainage. However, nutrient loss must have been reduced by using slowrelease fertiliser. If the fertiliser used were soluble in water, a common practice among farmers, nutrient loss in these treatments could be significant, especially in the event of heavy rainfall.

Water depths greater than field capacity increase nutrient leaching in water-soluble fertilisers (JIA et al., 2014; MENDES et al., 2016) and should only be used to reduce an excess of salts in the root zone. Leaching, when adopted as an irrigation strategy, should use the minimum amount of water in order to save water resources and avoid environmental contamination (KISEKKA et al., 2019). 
G. V. BOMFIM et al.

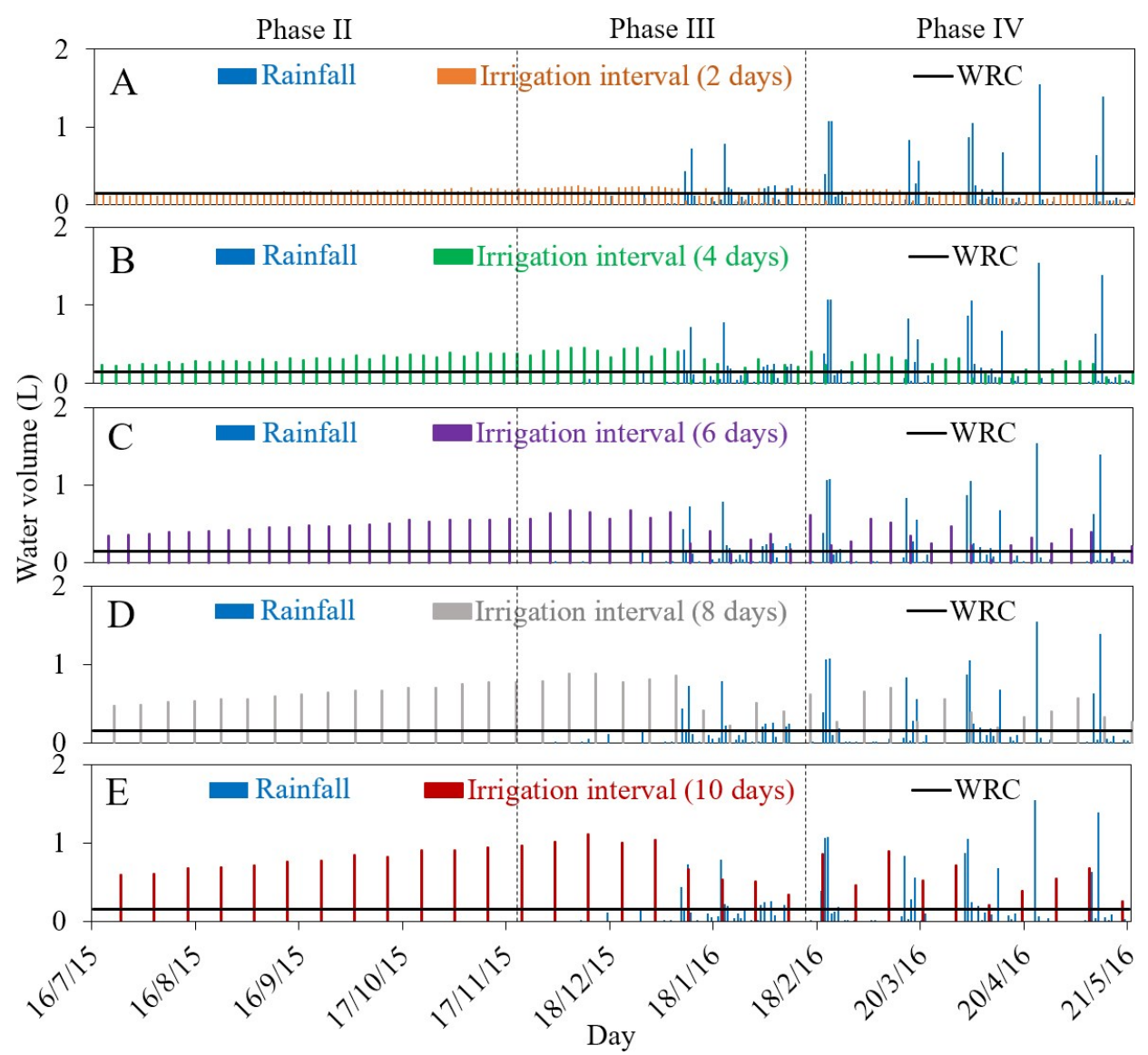

Figure 3. Accumulated volume of rainfall and irrigation for irrigation intervals of 2 (A), 4 (B), 6 (C), 8 (D) and 10 (E) days, during the phenological phases of the ornamental pineapple (Ananas comosus var. erectifolius) grown in pots, in the experiment carried out in a greenhouse, in Fortaleza, Ceará, Brazil. WRC $=$ water retention capacity.

\section{Vegetative growth in the ornamental pineapple}

Except for the width of the 'D' leaf, the vegetative growth variables of the ornamental pineapple were all influenced by the irrigation interval (Table 2).
The number of leaves showed the greatest values at the irrigation intervals of 2 and 4 days. The mean value of these treatments, estimated at approximately 46 units, was $18 \%$ higher than the approximate mean value of 39 leaves per plant, estimated for the irrigation intervals of 6,8 and 10 days.

Table 2. Summary of the analysis of variance and test of mean values for the vegetative growth variables of the ornamental pineapple (Ananas comosus var. erectifolius) grown in pots in a greenhouse, in Fortaleza, Ceará, Brazil.

\begin{tabular}{lccccc}
\hline \multirow{2}{*}{ Source of variation } & \multicolumn{5}{c}{ F-test $(\mathrm{P}<0.05)$} \\
\cline { 2 - 5 } & NL (unit) & LL $(\mathrm{cm})$ & LW $(\mathrm{cm})$ & DR $(\mathrm{cm})$ & PH $(\mathrm{cm})$ \\
\hline Treatment & $11.4^{*}$ & $5.5^{*}$ & $2.1^{\mathrm{ns}}$ & $6.9^{*}$ & $11.5^{*}$ \\
CV (\%) & 6.2 & 9.4 & 4.1 & 8.4 & 8.1 \\
\hline Irrigation interval (day) & & Scott-Knott test $(\mathrm{P}<0.05)$ & & $58.3 \mathrm{a}$ \\
\hline 2 & $46.7 \mathrm{a}$ & $47.9 \mathrm{a}$ & 2.8 & $65.7 \mathrm{a}$ & $55.0 \mathrm{a}$ \\
4 & $46.6 \mathrm{a}$ & $41.8 \mathrm{~b}$ & 2.7 & $72.3 \mathrm{a}$ & $51.4 \mathrm{a}$ \\
8 & $39.9 \mathrm{~b}$ & $39.2 \mathrm{~b}$ & 2.7 & $64.4 \mathrm{a}$ & $44.4 \mathrm{~b}$ \\
10 & $40.7 \mathrm{~b}$ & $39.2 \mathrm{~b}$ & 2.6 & $57.8 \mathrm{~b}$ & $41.8 \mathrm{~b}$ \\
\hline
\end{tabular}

${ }^{*}=$ significant; ${ }^{\mathrm{ns}}=$ not significant; mean values followed by the same or no letters in a column do not differ by Scott-Knott test; $\mathrm{CV}=$ coefficient of variation; $\mathrm{NL}=$ number of leaves; $\mathrm{LL}$ and $\mathrm{LW}=$ length and width of the 'D' leaf; $\mathrm{DR}=$ diameter of the rosette; $\mathrm{PH}=$ plant height. 
The greatest length of the 'D' leaf occurred at the irrigation interval of 2 days. The estimated value for this treatment, $47.9 \mathrm{~cm}$, was $23.1 \%$ higher than the mean value of $38.9 \mathrm{~cm}$, estimated for the irrigation intervals of $4,6,8$ and 10 days.

The width of the 'D' leaf, the only variable not influenced by the treatments, had an estimated mean value of $2.7 \mathrm{~cm}$.

The diameter of the rosette was more significant at the irrigation intervals of 2,4 and 6 days. The mean value estimated for these treatments, $67.5 \mathrm{~cm}$, was $20.1 \%$ higher than the mean value of $56.2 \mathrm{~cm}$, estimated for the irrigation intervals of 8 and 10 days.

The greatest values for plant height occurred at the irrigation intervals of 2, 4 and 6 days. The mean values for these treatments, calculated as 54.9 $\mathrm{cm}$, was $27.4 \%$ higher than the mean value of 43.1 $\mathrm{cm}$, estimated for the irrigation intervals of 8 and 10 days.

Regardless of the differences in leaf growth, the plants subjected to all of the irrigation intervals were classified for use in pots, as they showed a length for the ' $\mathrm{D}$ ' leaf, diameter for the rosette, and plant height of less than $60.0,80.0$ and $65.0 \mathrm{~cm}$ respectively (SOUZA et al., 2012a).

In general, an increase in irrigation interval reduced the vegetative growth of the crop due to an increase in the water deficit. The irrigation intervals that most affected the crop were 4, 6, 8 and 10 days; of these, the intervals of 8 and 10 days resulted in the smallest vegetative growth, due to the plant being more exposed to the effects of water deficit.

Water deficit, depending on level and duration, can affect the morpho-physiological responses of several ornamental species. Morphologically, it can reduce growth (leaf area, plant height and width, stem diameter, leaf number, etc.) and impair the aesthetics of the foliage (changes in colour, necrosis, abscission, etc.) (SÁNCHEZBLANCO et al., 2019). Physiologically, it can cause stomatal closure and a reduction in gas exchange and photosynthesis (TOSCANO; FERRANTE; ROMANO, 2019). This situation decreases nutrient absorption by the plants, which may show symptoms of deficiency. In the ornamental pineapple ( $A$. comosus var. erectifolius), a deficiency of $\mathrm{P}, \mathrm{Ca}$ and $\mathrm{S}$, for example, can reduce the number and size of the leaves and the height of the plants (VIÉGAS et al., 2014).

The reduction in vegetative growth with the increase in irrigation interval, although significant in some treatments, was no greater than $22 \%$ for each variable. It is therefore possible that the effects of the water deficit were reduced by the metabolism of the crop and by the rainfall.

The pineapple can change its metabolism from $\mathrm{C}_{3}$ to CAM when under conditions of stress caused by water deficit (ARAGÓN et al., 2013). With CAM, the plants close their stomata during the day to reduce water loss, and open them at night to fix $\mathrm{CO}_{2}$, with the aim of increasing water use efficiency and adaptation to the lack of water (ZHANG; LIU; MING, 2014).

From the second half of phase III until the end of phase IV, the rainfall occasionally reduced the effects of the treatments (Figure 3 ). The distribution of the rainfall must have been more important in supplying water than the intensity, since small containers have a limited capacity for collecting and retaining water (FASCELLA; ROUPHAEL, 2017).

It is worth remembering that, despite the rainfall, the period during which the plants were subjected to the full effects of the treatments, from the start of phase II until the first half of phase III (about seven months with no rain), was enough to reduce growth and affect the aesthetics of some of the plants.

Plant aesthetics were affected due to yellowing of the leaves (chlorosis). This symptom occurred in some plants at irrigation intervals of 4,6 and particularly, 8 and 10 days (Figure 4 ).

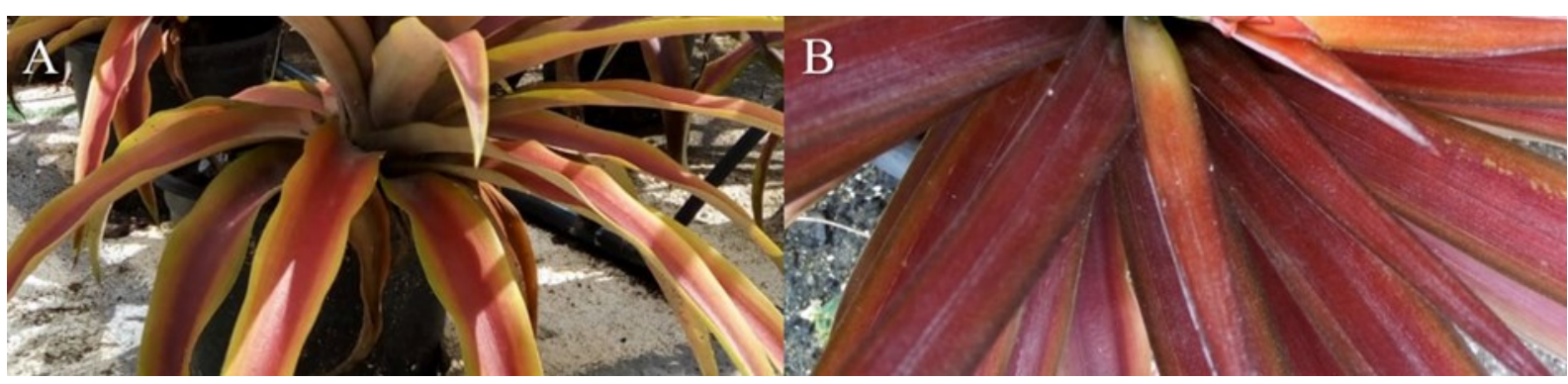

Figure 4. Presence (A) and absence (B) of leaf chlorosis in plants of the ornamental pineapple (Ananas comosus var. erectifolius) grown in pots, in the experiment carried out in a greenhouse (16/7/2015 to 21/05/2016), in Fortaleza, Ceará, Brazil. 
In the edible pineapple, the symptoms of water stress on the leaves occur slowly, and in addition to wilting, curling of the leaf margins and loss of turgidity, can be characterised by yellowing of the leaves (CARR, 2012). In the pineapple, the mechanism of stomatal closure for drought adaptation (CAM), by reducing water absorption, decreases $\mathrm{CO}_{2}$ assimilation and nutrient uptake (TOSCANO; FERRANTE; ROMANO, 2019), which may lead to a deficiency. In the ornamental pineapple (Ananas comosus var. erectifolius), a deficiency of $\mathrm{N}$ and $\mathrm{Mg}$, for example, alters the colour of the leaves, which may take on a pale green or yellowish colour along their entire edge (VIÉGAS et al., 2014).

\section{Reproductive growth in the ornamental pineapple}

As shown in Table 3, only the rate of flowering and the percentage of commercial plants were influenced by the irrigation interval.

Table 3. Summary of the analysis of variance and test of mean values for the reproductive growth variables of the ornamental pineapple (Ananas comosus var. erectifolius) grown in pots in a greenhouse, in Fortaleza, Ceará, Brazil.

\begin{tabular}{|c|c|c|c|c|c|c|c|c|c|}
\hline \multirow{2}{*}{ Source of variation } & \multicolumn{9}{|c|}{ F-test $(\mathrm{P}<0.05)$} \\
\hline & RF (\%) & $\mathrm{PD}(\mathrm{cm})$ & PL (cm) & $\mathrm{CD}(\mathrm{cm})$ & CL (cm) & $\mathrm{SD}(\mathrm{cm})$ & $\mathrm{SL}(\mathrm{cm})$ & $\mathrm{C} / \mathrm{S}$ & $\mathrm{CP}(\%)$ \\
\hline Treatment & $3.0^{*}$ & $2.9^{\mathrm{ns}}$ & $0.7^{\mathrm{ns}}$ & $1.9^{\mathrm{ns}}$ & $0.8^{\mathrm{ns}}$ & $1.0^{\mathrm{ns}}$ & $2.0^{\mathrm{ns}}$ & $1.3^{\mathrm{ns}}$ & $17.2^{*}$ \\
\hline CV (\%) & 16.1 & 13.1 & 21.3 & 22.7 & 18.3 & 7.1 & 15.1 & 13.0 & 14.6 \\
\hline Irrigation interval (day) & \multicolumn{9}{|c|}{ Scott-Knott test $(\mathrm{P}<0.05)$} \\
\hline 2 & $93.7 \mathrm{a}$ & 1.0 & 22.6 & 3.0 & 3.5 & 2.7 & 3.4 & 1.2 & $93.7 \mathrm{a}$ \\
\hline 4 & $87.5 \mathrm{a}$ & 0.9 & 23.3 & 2.8 & 4.2 & 2.7 & 4.1 & 1.2 & $75.0 \mathrm{~b}$ \\
\hline 6 & $81.2 \mathrm{a}$ & 0.9 & 20.3 & 2.7 & 3.6 & 2.5 & 3.2 & 1.2 & $68.7 \mathrm{~b}$ \\
\hline 8 & $68.8 \mathrm{~b}$ & 0.7 & 19.0 & 2.3 & 3.5 & 2.4 & 3.3 & 1.0 & $50.0 \mathrm{c}$ \\
\hline 10 & $68.8 \mathrm{~b}$ & 0.8 & 23.1 & 2.0 & 3.8 & 2.6 & 3.4 & 1.3 & $43.7 \mathrm{c}$ \\
\hline
\end{tabular}

${ }^{*}=$ significant $^{\text {ns }}=$ not significant; mean values followed by the same or no letters in a column do not differ by Scott-Knott test; $\mathrm{CV}=$ coefficient of variation; $\mathrm{RF}=$ rate of flowering; $\mathrm{PD}$ and $\mathrm{PL}=$ diameter and length of the peduncle; $\mathrm{CD}$ and $\mathrm{CL}=$ diameter and length of the crown; $\mathrm{SD}$ e $\mathrm{SL}=$ diameter and length of the syncarp; $\mathrm{C} / \mathrm{S}=$ crown $/$ syncarp ratio; $\mathrm{CP}=$ commercial plant.

The highest rates of flowering occurred at the irrigation intervals of 2, 4 and 6 days, and ranged from 93.7 to $81.2 \%$, with a mean value of $87.5 \%$. The lowest rates, with a mean value of $68.8 \%$, occurred at the irrigation intervals of 8 and 10 days. The three shortest irrigation intervals resulted in a mean flowering rate $27.2 \%$ greater than at the two longest intervals.

Considering the highest and lowest rates of flowering at the irrigation intervals of 2, 4 and 6 days, between 10 and $20 \%$ of the plants did not flower. At the irrigation intervals of 8 and 10 days, this value was around $30 \%$. This failure (delay) to flower is probably related to the efficiency of the ethephon and to the maturity of the crop.

In the edible pineapple, ethephon efficiency for flowering is usually greater than $90 \%$, but is not total, as it is affected by both biotic (cuticles, trichomes, etc.) and abiotic factors (temperature, humidity, etc.) (CUNHA, 2005).

The sensitivity of the pineapple to artificial floral induction depends on the maturity of the plants, which need to reach the appropriate size and chronological age to respond to ethylene (CUNHA, 2005; POEL; CEUSTERS; PROFT, 2009). As such, it is likely that the lower rates of flowering at the irrigation intervals of 8 and 10 days were due to smaller plant growth. It worth noting that the length of the 'D' leaf, one of the main parameters indicating plant maturity (POEL; CEUSTERS; PROFT, 2009), also had the lowest values in these treatments. In the ornamental pineapple (Ananas comosus var. erectifolius), the lack of information on floral induction based on plant size makes it difficult to establish a minimum limit on when to apply the floral inductor.

The growth of the floral stems in the ornamental pineapple was not influenced by the treatment. The floral stems of the plants that responded to floral induction showed no morphological anomalies (shape, colour, spots, mutations, etc.) and presented the dimensions necessary to classify the plants for use in pots, i.e. length and diameter of the syncarp of less than 5.0 and $3.0 \mathrm{~cm}$, length of the peduncle and crown of less than 30.0 and $5.0 \mathrm{~cm}$, and a crown to syncarp ratio of up to 1.5 (SOUZA et al., 2007; 2012a).

The water supplied by the rainfall must have been primarily responsible for reducing the effects of the treatments on the formation and growth of the 
floral stems. The explanation is that rainfall was more frequent and better distributed during the period between floral induction $(16 / 3 / 2016)$ and fruit production $(20 / 5 / 2016)$. Furthermore, it is possible that the CAM also reduced the effects of water deficit in the absence of rainfall, due to the plants adapting to the stress caused by the lack of water. As discussed above, CAM plants close their stomata during the day to reduce water loss and open them at night to increase $\mathrm{CO}_{2}$ fixation, which results in greater water use efficiency and therefore greater resistance to drought (AMIN et al., 2019).

The percentage of commercial plants was reduced by the plants that did not flower and by those plants where, even when flowering, the aesthetics were affected by the treatments.

The irrigation interval of two days resulted in the highest percentage of commercial plants, estimated at $93.7 \%$. This variable, considering the mean value for those treatments that showed no difference from one another, went down to $71.9 \%$ at the irrigation intervals of 4 and 6 days, and to only $46.9 \%$ at the irrigation intervals of 8 and 10 days. At the irrigation intervals of 4 and 6 days, and 8 and 10 days, the percentage of commercial plants was, on average, 12.4 and $21.8 \%$ less than the rate of flowering, due to the detrimental effects of the water deficit on the aesthetics of the plants (yellowing of the leaves).

These results demonstrate that the irrigation interval of 2 days had the least negative effect on the plants, given the high percentage of flowering and of commercial plants. The irrigation intervals of 4 and 6 days, although resulting in rates of flowering equal to the interval of 2 days, reduced the number of plants suitable for commercialisation. The irrigation intervals of 8 and 10 days were the most damaging to the crop, due to the lower rate of flowering and percentage of commercial plants.

\section{CONCLUSIONS}

Supplementary irrigation of the ornamental pineapple by surface drip, when carried out every 2 days, reduces water wastage and affords the greatest production of plants suitable for sale in pots. However, when carried out at intervals of 4, 6 and particularly, 8 and 10 days, it increases water loss due to excessive drainage, and reduces the productivity and aesthetic quality of the plants due to an increase in the water deficit.

Therefore, the recommended irrigation interval for the protected cultivation of the ornamental pineapple in pots is 2 days. Irrigation intervals of between 4 and 10 days are not recommended for this method of cultivation.

\section{ACKNOWLEDGEMENTS}

The authors would like to thank CAPES for their financial support, UFC for the use of the experimental area and infrastructure, and EMBRAPA for supplying the materials and providing scientific support.

\section{REFERENCES}

ALLEN, R. G. et al. Evapotranspiración del cultivo: guías para la determinación de los requerimientos de agua de los cultivos. Roma: FAO, 2006. 300 p. (Estudio FAO Riego e Drenaje, 56).

ALMEIDA, O. A. Irrigação em abacaxi. 1. ed. Cruz das Almas, BA: EMBRAPA-CNPMF, 1995. 33 p. (Documentos, 60).

ALVES, K. A. et al. Multiplication of ornamental pineapple in different concentrations of bap and periods evaluation of development in vitro. Bioscience Journal, 30: 188-198, 2014

AMIN, A. B. et al. Crassulacean acid metabolism abiotic stress-responsive transcription factors: a potential genetic engineering approach for improving crop tolerance to abiotic stress. Frontiers in Plant Science, 10: 1-8, 2019

ARAGÓN, C. et al. The physiology of ex vitro pineapple (Ananas comosus L. Merr. var MD-2) as CAM or $\mathrm{C}_{3}$ is regulated by the environmental conditions: proteomic and transcriptomic profiles. Plant Cell Reports, 32: 1807-1818, 2013.

AZEVEDO, P. V. de. et al. Water requirements of pineapple crop grown in a tropical environment, Brazil. Agricultural Water Management, 88: 201208, 2007.

BARBOSA, T. M. B. et al. Phosphorus sources: effects on growth and phosphorus fractions of Curauá (Ananas erectifolius L. B. Smith). Communications in Soil Science and Plant Analysis, 46: 1200-1211, 2015.

BRITO, C. F. B. et al. Physiological characteristics and yield of 'Pérola' pineapple in the semi-arid region. Revista Brasileira de Engenharia Agrícola e Ambiental, 21: 834-839, 2017.

CARR, M. K. V. The water relations and irrigation requirements of pineapple (Ananas comosus var. comosus): a review. Experimental Agriculture, 48: 488-501, 2012.

CUNHA, G. A. P. da. Applied aspects of pineapple 
flowering. Bragantia, 64: 499-516, 2005.

DAVIS, S. C. et al. Undervalued potential of crassulacean acid metabolism for current and future agricultural production. Journal of Experimental Botany, 70: 6521-6537, 2019.

FASCELLA, G.; ROUPHAEL, Y. Influence of container volume and irrigation system on photosynthesis, water productivity and growth of potted Euphorbia $\times$ lomi. Acta Scientiarum Polonorum Hortorum Cultus, 16: 163-171, 2017.

FRANCO, L. R. L. et al. Crescimento, produção e qualidade do abacaxizeiro 'Pérola' sob diferentes lâminas de irrigação. Revista Caatinga, 27: 132$140,2014$.

HAWERROTH, F. J. et al. Adubo de liberação lenta na produção de abacaxizeiro ornamental em vaso. 1. ed. Fortaleza, CE: Embrapa Agroindústria Tropical, 2014. 19 p. (Boletim de pesquisa e desenvolvimento, 95).

JIA, X. et al. Effect of different nitrogen and irrigation treatments on yield and nitrate leaching of summer maize (Zea mays L.) under lysimeter conditions. Agricultural Water Management, 137: 92-103, 2014.

JUNQUEIRA, A. H.; PEETZ, M. da S. Sustainability in Brazilian floriculture: introductory notes to a systemic approach. Ornamental Horticulture, 24: 155-162, 2018.

KISEKKA, I. et al. Uncertainties in leaching assessment in micro-irrigated fields using water balance approach. Agricultural Water Management, 213: 107-115, 2019.

LIMA, O. S. et al. Characterization and selection of ornamental pineapple hybrids with emphasis on sinuous stems and black fruits. Pesquisa Agropecuária Tropical, 47: 237-245, 2017.

MENDES, B. S. S. et al. Mecanismo fisiológicos e bioquímicos do abacaxi ornamental sob estresse salino. Revista Caatinga, 24: 71-77, 2011.

MENDES, W. C. et al. Potassium leaching in different soils as a function of irrigation depths. Revista Brasileira de Engenharia Agrícola e Ambiental, 20: 972-977, 2016.

PEREIRA, G. N. D. et al. Public perception and acceptance of ornamental pineapple hybrids. Horticultura Ornamental, 24: 116-124, 2018.
POEL, B. V; CEUSTERS, J.; PROFT, M. P. Determination of pineapple (Ananas comosus, MD-2 hybrid cultivar) plant maturity, the efficiency of flowering induction agents and the use of activated carbon. Scientia Horticulturae, 120: 58-63, 2009.

REIS, I. N. R. S. et al. Trocas gasosas e alocação de biomassa em plantas jovens de Curauá (Ananas erectifolius L. B. Smith) submetidas ao alagamento. Revista Brasileira de Biociências, 5: 507-509, 2007.

SÁNCHES-BLANCO, M. J. et al. Deficit irrigation as a strategy to control growth in ornamental plants and enhance their ability to adapt to drought conditions. The Journal of Horticultural Science and Biotechnology, 94: 137-150, 2019.

SANTANA, M. J. de. et al. Coeficientes de cultura do abacaxizeiro nas condições edafoclimáticas de Uberaba, MG. Revista Brasileira de Engenharia Agrícola e Ambiental, 17: 602-607, 2013.

SOUZA, E. H. de. et al. Genetic variation of the Ananas genus with ornamental potential. Genetic Resources and Crop Evolution, 59: 1357-1376, 2012a.

SOUZA, E. H. de. et al. Selection and use recommendation in hybrids of ornamental pineapple. Revista Ciência Agronômica, 45: 409-416, 2014.

SOUZA, F. V. D. et al. Caracterização morfológica de abacaxizeiros ornamentais. Magistra, 19: 319325,2007

SOUZA, O. P. de. et al. Pineapple production and physical quality under different irrigation frequencies and water depths. Irriga, 17: 534-546, $2012 b$.

TOSCANO, S.; FERRANTE, A.; ROMANO, D. Response of Mediterranean ornamental plants to drought stress. Horticulturae, 5: 1-20, 2019.

VIÉGAS, I. J. M. et al. Mineral composition and visual symptoms of nutrients deficiencies in Curauá plants (Ananas comosus var. erectifolius). Australian Journal of Crop Science, 8: 747-753, 2014.

ZHANG, J.; LIU, J.; MING, R. Genomic analyses of the CAM plant pineapple. Journal of Experimental Botany, 65: 1-10, 2014. 